\title{
Manufacture and Strength Analysis of Ergonomic Bicycle Helmet Made from Polymeric Foam Composite Strengthened by Oil Palm Empty Fruit Bunch Fiber with Free Fall Drop Test Method
}

\author{
Mahadi, ${ }^{\text {a,* }}$ \\ a) Department of Mechanical Engineering, Universitas Sumatera Utara, Medan, Indonesia \\ *Corresponding author: mahadimahad87@gmail.com
}

\section{Paper History}

Received: 06-February-2020

Received in revised form: 11-March-2020

Accepted: 30-March-2020

\section{ABSTRACT}

This article contains a study report on the manufacturing of bicycle helmet models that use polymeric foam composite materials strengthened by oil palm empty fruit bunch (OPEFB). The test results of mechanical polymeric foam obtain tensile stress $(\sigma \mathrm{t}) 1.17 \mathrm{MPa}$, compressive stress $(\sigma \mathrm{c}) 0.51 \mathrm{MPa}$, bending stress $(\sigma b) 3.94 \mathrm{MPa}$, modulus of elasticity (E) $37.97 \mathrm{MPa}$, density ( $\rho) 193(\mathrm{~kg} / \mathrm{m} 3)$. The testing results of thermal conductivity (k) with ASTM C177-04 standard obtain 0.096 $\mathrm{W} / \mathrm{mK}$. Aerodynamic simulation is carried out on 5 bicycle helmet models with different variations of air ventilation formations and obtained the M4A model that best met the ergonomic criteria. The simulation results of the M4A helmet model are max $65.668 \mathrm{~Pa}$ of air pressure $(\mathrm{Pu}), 26,8^{\circ} \mathrm{C}$ of inner wall temperature (Ti), $11.0724 \mathrm{~m} / \mathrm{s}$ of air velocity (vi) and 0.89 of drag coefficient (CD). Bicycle helmet manufacturing is carried out by hand lay-up method for shell layer and casting mold for liner by using GFRP polymer composite molds. Both layers are made by sandwich method with the composition of the shell layer is 100 grams resin, 15 grams glass fiber and 5 grams catalyst. The composition of the liner layer is 275 grams $(50 \%)$ of unsaturated Polyester 157 BQTN-EX resin, 27.5 grams (5\%) of OPEFB fiber, 247 grams (45\%) of Blowing Agent Polyurethane and 27.5 grams (5\%) of Methyl Ketone Peroxide catalyst (MEKPO). The toughness of the helmet is tested by using a free fall drop test with the standard of Consumer Product Safety Commission (CPSC) with the height of impact 1.5 meters. The free fall drop test
\end{abstract}

results are max $2.02 \mathrm{MPa}$ of the impact stress of the M4A bicycle helmet model ( $\sigma \mathrm{i})$ and max 283.77 joules of energy impact (Ei) which is close to the Consumer Product Safety Commission's (CPSC) standard value of 110 joules.

KEY WORDS: Ergonomic, Bicycle Helmet, Impact, OPEFB, Polymeric foam.

\subsection{INTRODUCTION}

Bicycle helmets which the good quality can protect the wearer from fatal injuries of an accident. The quality of a bicycle helmet is greatly influenced by the material and its manufacturing method. The materials commonly used to make bicycle helmets are Kevlar, Thermoplastic and Polystyrene for impact absorbing foam. Manufacturing technology generally uses injection molding and thermoforming [1].

This study uses ergonomic bicycle helmet design model which has strong characteristic, comfortable and aesthetic. The used material is Polymer Unsaturated Polyester BQTN-157 EX composite as the matrix, oil palm empty fruit bunch (OPEFB) as the reinforcement and polyurethane as the Blowing Agent. As catalyst that is useful for accelerating the freezing process, methyl ethyl ketone peroxide (MEKPO) catalyst is used.

This study aims to produce bicycle helmet products that meet ergonomic criteria. To meet these objectives, various tests are carried out both from the material and the geometrical structure of the helmet itself. The mechanical properties of the material are known by static testing, physical properties are tested for the thermal conductivity of the material and the structural strength of the bicycle helmet geometry is known by the free fall drop test. Testing is carried out by referring to ASTM standards and the Consumer Product Safety Commission (CPSC). 


\subsection{REVIEW OF LITERATURE}

Ergonomics is one of the requirements to achieve a qualified, certified and customer-need design. This science will become a simultaneous linkage and create synergy in idea's emergence and design processes. Ergonomics Product Design Scheme can be seen in Figure 1.

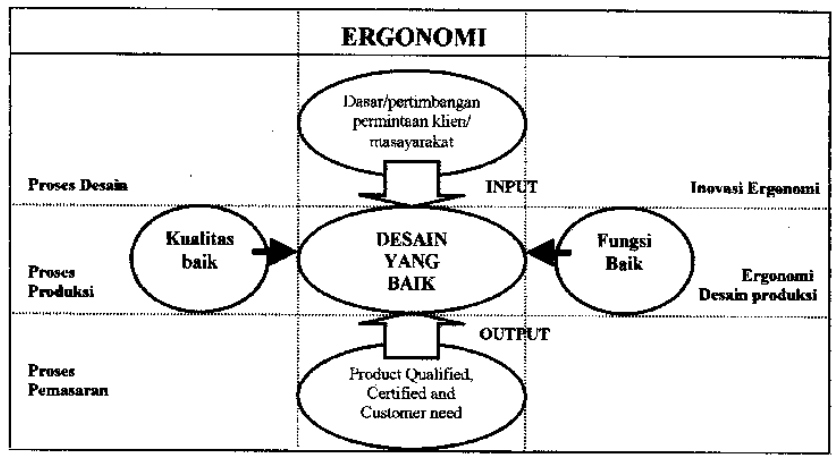

Figure 1: Ergonomics Product Design Scheme [4].

Product design is one of the scientific fields integrated with all of human life's aspects from time to time. Combining imaginary elements and orientation for finding solutions of various problems faced by humans, bridging aesthetics and technology which is dynamic and has a certain pattern in its development. The definition of the design can be seen from various perspectives and contexts, design can be a way to solve problem with a clear target [2] and design is an action and initiative to change human work [3].

Bicycle helmet's geometry structure construction shape is adjusted to the anatomical plane of the human head's shape. The anatomical plane is a structure to show the cross section of the human body and describe the location of the structures or direction of movements. In the anatomy of the human head, there are three basic areas used which are sagittal plane (basic), midsagittal plane (longitudinal) and coronal plane (transversal) [5], as shown in Figure 2.
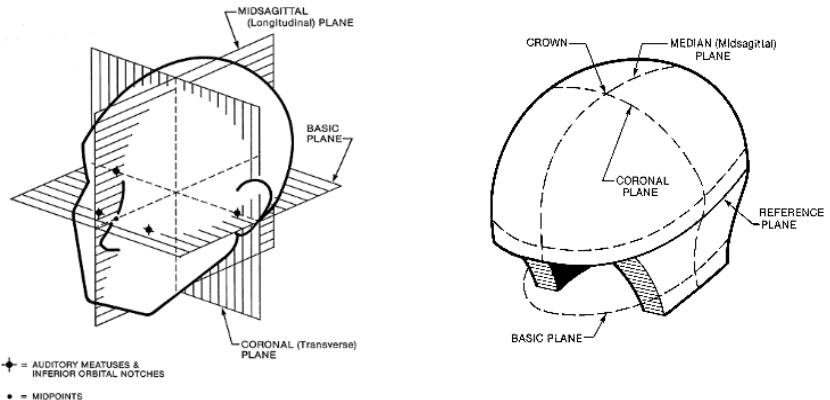

- moporin

Figure 2: Geometrical Structure of the Human Head's Anatomy and Helmet

Cycling can cause light to severe injury, like a head injury, which cause the death. The use of suitable head protection helmet can minimize the danger of the death or disability. The free fall drop test as in Figure 3 is used to test the helmet by dropping the helmet onto a flat anvil imitating the road surface.

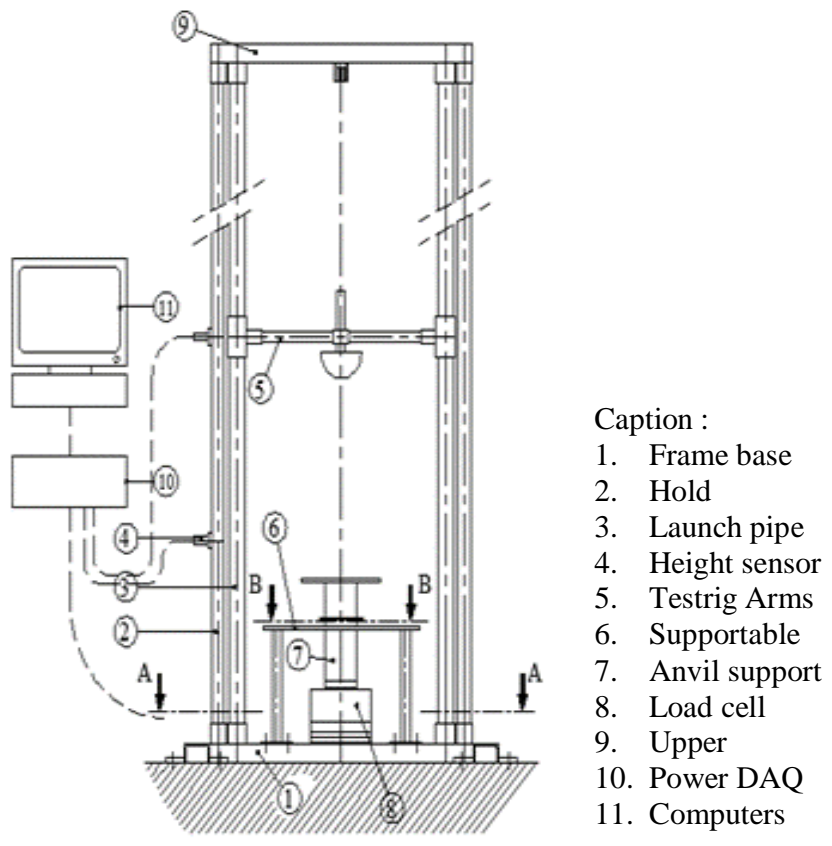

Figure 3: Free fall drop test impact construction

The application of energy conservation to a falling object is to predict the impact speed and kinetic energy but the impact strength cannot be predicted without knowing the level extent of the helmet absorbing the impact energy. Energy conservation is used as a tool to calculate the speed of a falling object before touching the surface. Dynamic energy in moving objects can be stated as follows:

Potential Energy, $\mathrm{PE}=\mathrm{mgh}$

Kinetic Energy, $\mathrm{KE}=\frac{1}{2} \mathrm{mv}^{2}$

The impact velocity, $v=\sqrt{2 g h}$

One of the most important things in riding a bicycle is the helmet as the protective headgear from collision injuries if an accident occurs. The formula used to measure the ability of a helmet to prevent head injuries is called the Head Critical Criterion (HIC):

$$
\mathrm{HIC}=\max \left\{\left[\frac{1}{t_{2}-t_{1}} \int_{t_{1}}^{t_{2}} a(t) d t\right]^{2.5}\left(t_{2}-t_{1}\right)\right\}
$$

where $t_{1}$ and $t_{2}$ are the time difference and $a$ is gravitational acceleration. The requirement for a protective helmet is that the Head Critical Criterion (HIC) must be under 1000.

The helmet product must pass a laboratory test in which the helmet is instrumented into head shape, inverted position and falling position for the measured distance to the anvil. To pass the test standard, the weight of the helmet must be a maximum of 300 grams during the test. Standard of helmet toughness testing is in every country. The three helmet testing standards most commonly used are EN1078, Consumer Product Safety Commission (CPSC), ASTMF1447 and Snell B-95. Table 1 shows the correlations between each standard for helmet toughness testing. 
Table1: Helmet test criteria [5].

\begin{tabular}{lllll}
\hline & CPSC & $\begin{array}{l}\text { ASTM } \\
\text { F1447 }\end{array}$ & $\begin{array}{l}\text { Snell } \\
\text { B-95 }\end{array}$ & $\begin{array}{l}\text { EN } \\
\mathbf{1 0 7 8}\end{array}$ \\
\hline $\begin{array}{l}\text { Drop height on flat } \\
\text { anvil (m) }\end{array}$ & 2.0 & 2.0 & 2.2 & 1.5 \\
\hline $\begin{array}{l}\text { Drop height on } \\
\text { hemispherical anvil (m) }\end{array}$ & 1.2 & 1.2 & 1.5 & N/A \\
\hline Head form weight $(\mathrm{kg})$ & 5 & 5 & 5 & 4 \\
\hline Failure threshold $(\mathrm{g})$ & 300 & 300 & 300 & 250 \\
\hline
\end{tabular}

Unsaturated polyester resin is a condensate polymer material formed based on the reaction between polyol which is combined organic with multiple alcohols. Unsaturated polyester resin is a type of thermoset polymer that has a long carbon chain structure.

Table 2: Characteristics of Unsaturated Polyester [6]

\begin{tabular}{lll}
\hline Mechanical Properties & Unit & Value \\
\hline Modulus Young $(\mathrm{E})$ & $\mathrm{GPa}$. & $2 \mathrm{~s} / \mathrm{d} 4,5$ \\
\hline Density $(\rho)$ & $\mathrm{mg} \cdot \mathrm{mm}^{3}$ & $1,2 \mathrm{~s} / \mathrm{d} 1,5$ \\
\hline Tensile Strength $\left(\sigma_{\mathrm{T}}\right)$ & $(\mathrm{MPa})$ & $40 \mathrm{~s} / \mathrm{d} 90$ \\
\hline
\end{tabular}

The reinforcement in composites in the form of aligned or short fiber is commonly used in Polymer Matrix Composite (PMC). Oil palm empty fruit bunch (OPEFB) fiber is a composite reinforcement from nature that is widely obtained in the tropics. Each OFEFB fiber physically contains fiber ingredients such as lignin $(16.19 \%)$, cellulose (44.14\%) and hemicelluloses $(19.28 \%$ ) which are similar to wood-building chemicals [7].

OPEFB fiber has low tensile strength, while tensile modulus is rather conservative among other natural fibers [8] as shown in table 3 showing Tensile strength and Tensile modulus of some natural fibers.

Table 3: Tensile Strength and Tensile Modulus of some Natural Fibers [9]

\begin{tabular}{lcc}
\hline Natural Fiber & $\begin{array}{c}\text { Average Tensile } \\
\text { Strength(MPa) }\end{array}$ & $\begin{array}{c}\text { Tensile Modulus } \\
\text { (GPa) }\end{array}$ \\
\hline Bamboo & $25-35$ & - \\
(EFB) & 253 & 16 \\
Coir, cocoas & 220 & 6 \\
Sisal & $400-600$ & 38 \\
Jute & $430-530$ & $10-30$ \\
Hemp & $550-900$ & 70 \\
\hline
\end{tabular}

Polymeric foam is one of engineered Polymer Matrix Composite (PMC) forms with the formation of air bubbles of which purpose is to form a lightweight and strong material. The type of blowing agent that is widely used is polyurethane, which is a type of polymer that contains urethane tissue, namely - $\mathrm{NH}$ CO-O-.

\subsection{RESEARCH METHODOLOGY}

\subsection{Material}

The ingredients used are:

- Unsaturated Polyester BQTN-157 EX resin as a composite matrix.
- Polyurethane which is a reaction between polyol and isocyanate as blowing agents.

- Methyl Ethyl Ketone Peroxide (MEKPO) catalyst.

- Palm empty fruit bunch fiber (EFB) as filler.

\subsection{Equipment}

The equipment used for is:

- Static mechanical test equipment HT-9502 Computer Hydraulic Universal Testing Machine.

- Free fall drop test.

\subsection{Helmets Manufacturing}

The research material is Unsaturated Polyester BQTN-157 EX resin as the matrix, EFB fiber as a polymeric foam and polyurethane reinforcement which is a reaction between polyol and isocyanate as blowing agents. Testing of tensile strength, bending strength, compressive strength, thermal conductivity and density are carried out on the material according to ASTM standards.

Specimens are made in several test samples that varied in three compositions, namely $70 \%$ Resin, $25 \%$ BA, $5 \%$ fiber, and $5 \%$ catalyst for composition I, $60 \%$ resin, $35 \%$ BA, $5 \%$ fiber, and $5 \%$ catalyst for composition II and 50\% resin, $45 \%$ BA, $5 \%$ fiber, and $5 \%$ catalyst as composition III. Mechanical properties testing are carried out in a closed room with room temperature of $25^{\circ} \mathrm{C}$ with use a Shimadzu Servopulser static test.

The bicycle helmet design is done by using AutoCAD Software for 2D design and Solid work Software for 3D images. The bicycle helmet made in this study is a Half Face BMX model bicycle helmet and has a dimension of $264 \mathrm{~mm}$ in length, $184 \mathrm{~mm}$ in width, and $154 \mathrm{~mm}$ in height with a circumference of M (560 580) $\mathrm{mm}$.

The simulation is done using Ansys workbench software. The characteristics obtained from the aerodynamic simulation results are air pressure, the temperature of the inner wall of the helmet, and the speed of the air around the helmet. Aerodynamic simulations are carried out on 5 variations of the formation of wind channels on 5 helmet models with codes M1A, M2A, M3A, M4A and M5A. Data input of fluid material and OPEFB fiber material included as simulation parameters are Density of OPEFB fiber $=193 \mathrm{~kg} / \mathrm{m} 3$, Thermal Conductivity $=0.096 \mathrm{~W} / \mathrm{mK}$, Speed $($ Velocity $)=5.6 \mathrm{~m} / \mathrm{s}$ and ambient temperature $=303 \mathrm{~K}\left(29,8^{\circ} \mathrm{C}\right)$.
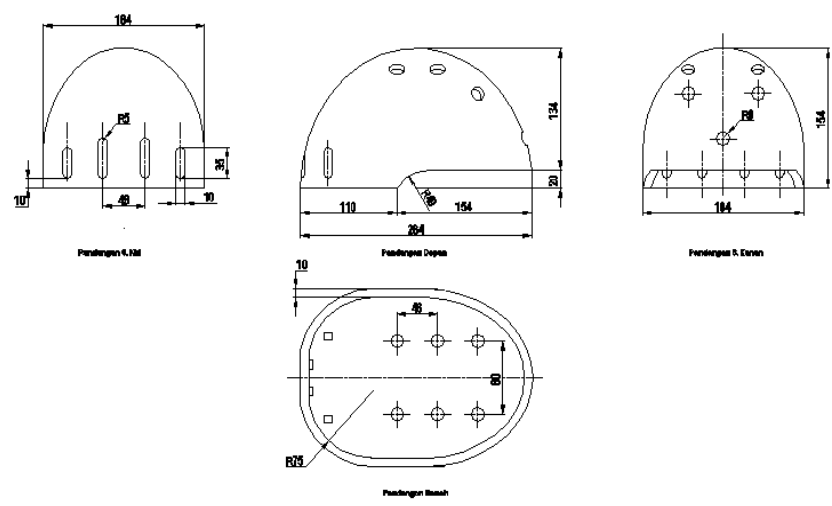

Figure 4. Model BMX-M4A 
The bicycle helmet made is an aerodynamic simulation model that is a model of Half Face BMX-M4A type with dimensions of $264 \mathrm{~mm}$ in length, $184 \mathrm{~mm}$ in width, and $154 \mathrm{~mm}$ in height with a head circumference of $580 \mathrm{~mm}$ (M size) as shown in Figure 4.

The Polymeric Foam helmet bicycle materials are made by using composition 3 which are OPEFB fiber 5\% (27.5gr), unsaturated Polyester 157 BQTN-EX 50\% (275gr) resin, Blowing agent $45 \%$ Polyurethane (247 gr) and Methyl Keton Peroxide (MEKPO) catalyst 5\% (27.5 gr). The method for mixing the materials is first by stirring powder with the resin until evenly \pm 2 minutes, then adding the mixture with catalyst and stir until evenly \pm 1 minute and the last, adding BA and stir until evenly \pm 30 seconds. The technique for gravity casting the pattern for vertical position is by pouring the composite material into the mold cavity slowly with the pouring time of 30 seconds then installing the mold dies after pouring.

\subsection{Experimental Setup}

The free fall drop test aims to determine the stress response on the bicycle helmet due to the effect of wave propagation with a high wave propagation rate. The tested bicycle helmet has $264 \mathrm{~mm}$ in length of dimension, $184 \mathrm{~mm}$ in width, and $154 \mathrm{~mm}$ in height with a head circumference of $580 \mathrm{~mm}$. The mass of the $5 \mathrm{~kg}$ test rig (CPSC standard) and the mass of the printed bicycle helmet vary from 328 to $451 \mathrm{gr}$. The test is carried out at room temperature $25^{\circ} \mathrm{C}$ and impacted height $1.5 \mathrm{~m}$.

The free fall drop test set-up is as follows:

- Load cell connectivity, sensor position, USB cable and DAQ Power, Lab-Jack U3-LV.

- Activate DAQ software for Helmet Drop testing from the desktop icon.

- Load cell and load cell bearing are installed properly as well as anvil and anvil support as shown in Figure 5.

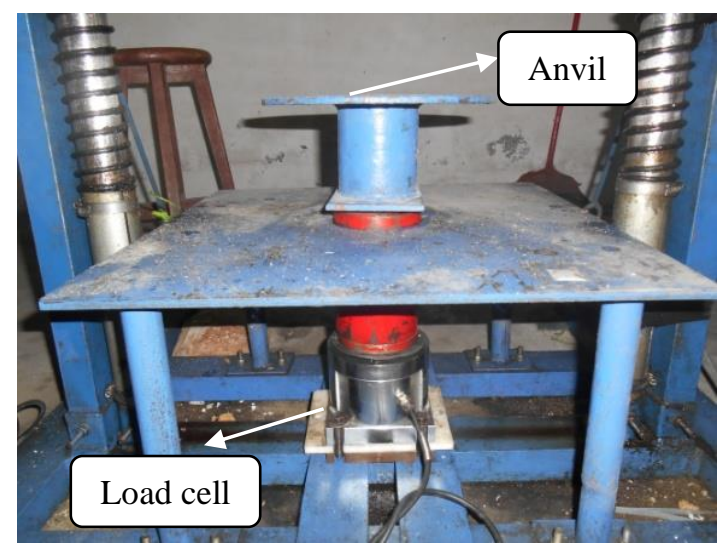

Figure 5: Anvil support

- Install flat anvil on anvil support according to the data retrieval testing requirements.

- Installation of test specimens on the test rig.

Variations in the impact of free fall are given at the top, front and the side of the helmet by considering that cyclists have the most accidents occurring in those sections. The bicycle helmet samples tested amounted to 9 units.

\subsection{RESULTS AND DISCUSSION}

The material for the helmet compiler chosen is the lightest one which is the composition 3 with the result of mechanical testing is Tensile Strength $(\sigma \mathrm{t}) 1.17 \mathrm{MPa}$, Compressive Strength $(\sigma \mathrm{c}) 0.51$ $\mathrm{MPa}$, Bending Strength $(\sigma \mathrm{b}) 3.94 \mathrm{MPa}$, Thermal conductivity (k) $=0.096 \mathrm{~W} / \mathrm{mK}$, Modulus of Elasticity $(\mathrm{E}) 37.97 \mathrm{MPa}$ is greater than of previous experiment result 17.22 MPa, Density $(\rho) 193$ $(\mathrm{kg} / \mathrm{m} 3)$.

The most ergonomic bicycle helmet of aerodynamic simulations is M4A model with specifications of $10 \mathrm{~mm}$ thickness, 11 total ventilations, max air pressure at the front of the helmet 107.4 Pa, max temperature on the inner wall of the helmet $26,8^{0} \mathrm{C}$, volume $857.060 \mathrm{~mm}^{3}$, max air speed $13.4 \mathrm{~m} / \mathrm{s}$ and drag coefficient (CD) 0.9. Contour Simulation of Aerodynamics M4A helmet type as shown in Figure 6.
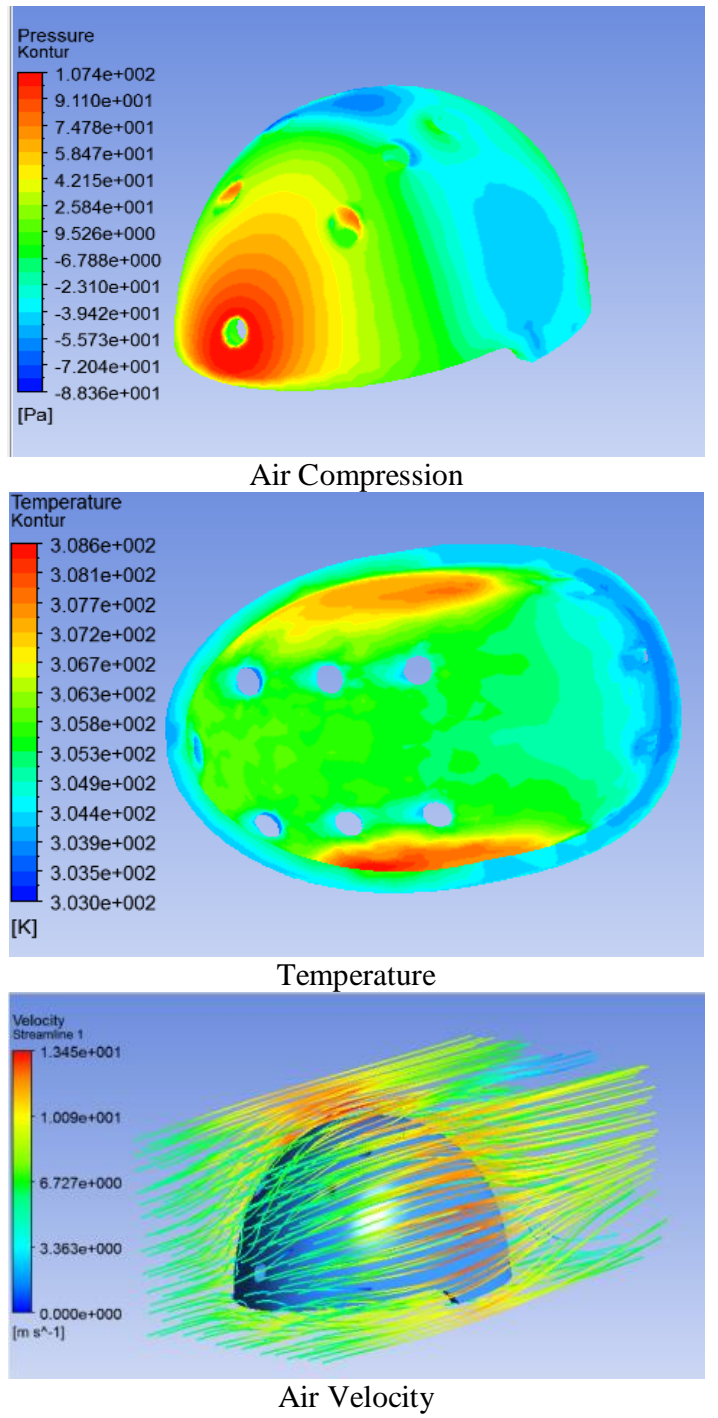

Figure 6: Contour Simulation of Aerodynamics M4A Helmet Type 
The result of printed design and product bicycle helmets before finishing and painting is shown in Figure 7 with specification of $264 \mathrm{~mm}$ in length, $184 \mathrm{~mm}$ in width, $154 \mathrm{~mm}$ in height, head circumference $580 \mathrm{~mm}, 11$ ventilations and $10 \mathrm{~mm}$ thickness.

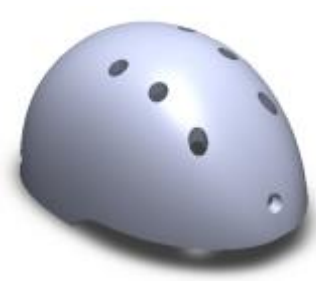

(a)

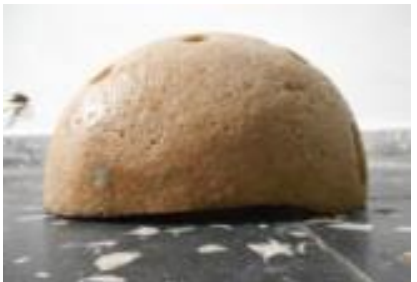

(b)
Figure 7: (a) BMX-M4A Model Design Results (b) Product

The result of the drop test of 9 samples, with impact points on the top, front, side and impacted height $1.5 \mathrm{~m}$ is shown in Figure 8 to10.
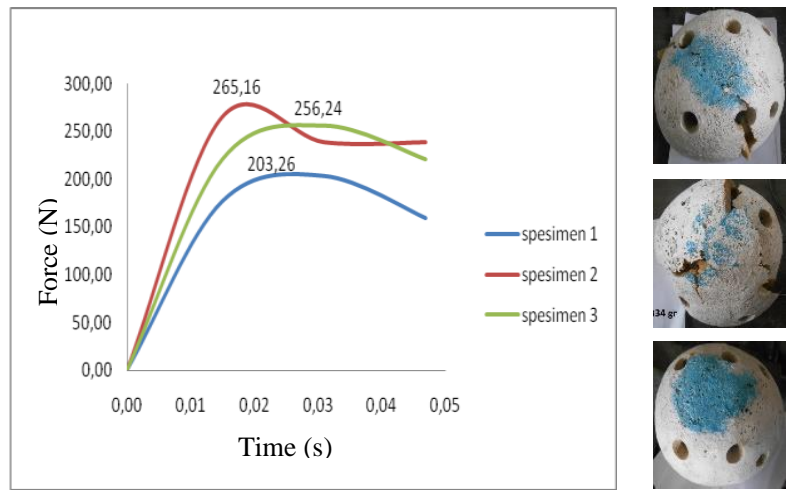

Figure 8: Top impact point

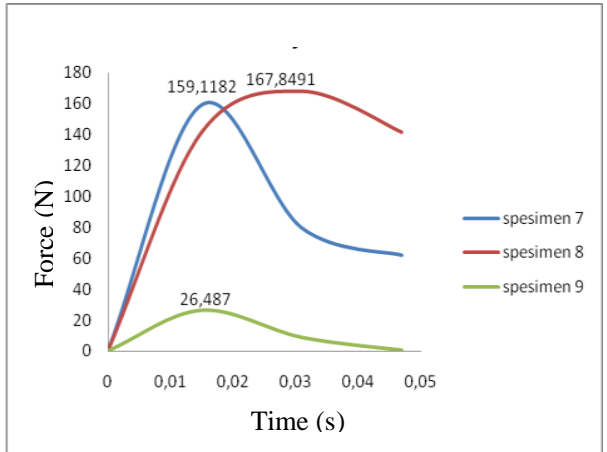

Figure 9: Front impact point

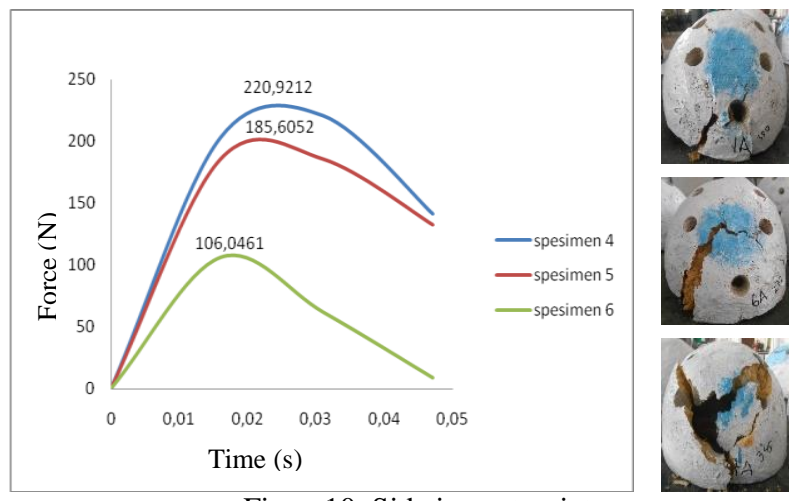

Figure10: Side impact point

The total energy that occurs on the experiment is the measured force impact $(\mathrm{Fi})$ multiplied by height $(\mathrm{h})$. Theoretical impact energy is mass multiplication with acceleration due to gravity (g) and altitude, and energy (Ei) absorbed by bicycle helmet which is the difference in experimental total impact energy reduced by theoretical energy. The Impact Energy data as shown in Table 4, 5 and 6.

Table 4: Impact Energy Absorption

\begin{tabular}{|c|c|c|c|c|c|}
\hline Helmet & $\begin{array}{c}\text { Mass of Helmet } \\
+ \text { Test Rig } \\
\text { (kg) }\end{array}$ & $\begin{array}{c}\text { Theoritical Impact } \\
\text { Energy, Et }=\text { m.g.h } \\
\text { (Joule) }\end{array}$ & $\begin{array}{c}\text { Impact } \\
\text { Force } \\
\left(\mathbf{F}_{\mathbf{i}}\right)(\mathbf{N})\end{array}$ & $\begin{array}{c}\text { Experimental } \\
\text { Ee }=F_{\text {i.h }} \\
(\text { Joule })\end{array}$ & $\begin{array}{c}\text { Impact Energy } \\
\text { Absorbtion } \\
\text { E }_{\mathrm{i}}=\text { Ee-Et (Joule) }\end{array}$ \\
\hline 1 & 5,328 & 78,40 & 203,26 & 304,89 & 226,49 \\
\hline 2 & 5,334 & 78,49 & 265,16 & 397,74 & 319,25 \\
\hline 3 & 5,354 & 78,78 & 256,24 & 384,36 & 305,58 \\
\hline 4 & 5,350 & 78,73 & 220,92 & 331,38 & 252,65 \\
\hline 5 & 5,272 & 77,58 & 185,6 & 278,4 & 200,82 \\
\hline 6 & 5,345 & 78,65 & 106,04 & 159,06 & 80,41 \\
\hline 7 & 5,296 & 77,93 & 159,12 & 238,68 & 160,75 \\
\hline 8 & 5,360 & 78,87 & 167,85 & 251,77 & 172,90 \\
\hline 9 & 5,341 & 78,59 & 26,48 & 39,72 & $-38,87$ \\
\hline
\end{tabular}

Table 5: Impact Force (F) and Impact Energy (Ei)

\begin{tabular}{cccccc}
\hline \multicolumn{4}{c}{ Average Force $(\boldsymbol{F})$ and Impact Energy $\left(\boldsymbol{E}_{\boldsymbol{i}}\right)$} \\
\hline \multicolumn{2}{c}{ Top } & \multicolumn{2}{c}{ Front } & \multicolumn{2}{c}{ Side } \\
\hline Impact & Impact & Impact & Impact & Impact & Impact \\
Force & Energy & Force & Energy & Force & Energy \\
$\left(\mathrm{F}_{\mathrm{i}}\right)(\mathrm{N})$ & $\left(\mathrm{E}_{\mathrm{i}}\right)(\mathrm{Joule})$ & $\left(\mathrm{F}_{\mathrm{i}}\right)(\mathrm{N})$ & $\left(\mathrm{E}_{\mathrm{i}}\right)(\mathrm{Joule})$ & $\left(\mathrm{F}_{\mathrm{i}}\right)(\mathrm{N})$ & $\left(\mathrm{E}_{\mathrm{i}}\right)(\mathrm{Joule})$ \\
\hline 241,55 & 283,77 & 170,85 & 177,96 & 117,81 & 98,26 \\
\hline
\end{tabular}

Table 6: Impuls and Impact Time

\begin{tabular}{cccccc}
\hline \multicolumn{5}{c}{ Average Impuls (I) and Impact Time $(\boldsymbol{t})$} \\
\hline \multicolumn{3}{c}{ Top } & \multicolumn{3}{c}{ Front } \\
\hline $\begin{array}{c}\text { Time } \\
(\mathrm{sec})\end{array}$ & $\begin{array}{c}\mathrm{I} \\
(\mathrm{Ns})\end{array}$ & $\begin{array}{c}\text { Time } \\
(\mathrm{sec})\end{array}$ & $\begin{array}{c}\text { I } \\
(\mathrm{Ns})\end{array}$ & $\begin{array}{c}\text { Time } \\
(\mathrm{sec})\end{array}$ & $\begin{array}{c}\text { I } \\
(\mathrm{Ns})\end{array}$ \\
\hline 0,026 & 6,28 & 0,031 & 5,29 & 0,031 & 3,65 \\
\hline
\end{tabular}


In the free fall drop testing of commercial bicycle helmets at the 1.5 meters impacted height, it gets the impact force data (Fi) $441.84 \mathrm{~N}$, time $0.125 \mathrm{~s}$, impact stress ( $\sigma \mathrm{i}) 3.78 \mathrm{MPa}$ and impulses 55.23 Ns. While the experimental impact energy is 662.76 joules, the theoretical impact energy is 107.12 joules and the absorbed energy (Ei) is 555.64 joules.

Table 7: Result of free fall drop drop test

\begin{tabular}{ll}
\hline \multicolumn{1}{c}{ Parameters } & \multicolumn{1}{c}{ Value } \\
\hline Impact Force $\left(\mathrm{F}_{\mathrm{i}}\right)(\max )$ & $241,55 \mathrm{~N}$ \\
Impact Energy $\left(\mathrm{E}_{\mathrm{i}}\right)(\max )$ & 283,77 joule \\
Impuls $(\mathrm{I})(\max )$ & $6,28 \mathrm{Ns}$ \\
Impact stress $\left(\sigma_{\mathrm{i}}\right)(\max )$ & $2,02 \mathrm{MPa}$ \\
Mass $(\mathrm{m})$ & $331 \mathrm{~g}$ \\
\hline
\end{tabular}

As the objectives of this study is to design an ergonomic bicycle helmet, and from the result of the study of the materials to make the helmet, the aerodynamic simulation of the helmet model, the temperature distribution and the toughness of the helmet, the model produced is obtained as shown in Figure 11.

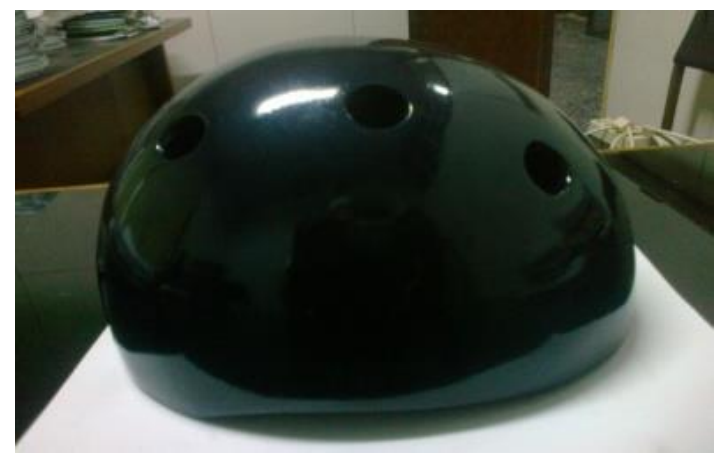

Figure 11. The Production of Helmet

\section{CONCLUSION}

Based on the data from the study results, it can be concluded as follows:

1) The best helmet model from aerodynamic simulation results on 5 bicycle helmet design models with variations of 5 air channel formations are M4A helmet models with $10 \mathrm{~mm}$ thickness, 11 ventilations, max helmet air pressure 107.4 Pa, max temperature on the inner wall of the helmet $26,8^{\circ} \mathrm{C}$, the volume of the geometry structure $857,060 \mathrm{~mm}^{3}$, max air velocity of $13.4 \mathrm{~m} / \mathrm{s}$ and air drag coefficient (CD) 0.9 . The shape of the helmet model's geometric structure is not too aerodynamic when compared to the streamlined body and streamlined half-body shapes with $\mathrm{CD}$ values of 0.04 and 0.09 .

2) Bicycle helmet products are made of polymeric foam material with average mechanical and physical properties and are tensile stress of $1.17 \mathrm{MPa}$, compressive stress of $0.51 \mathrm{MPa}$, bending stress of $3.94 \mathrm{MPa}$, modulus of elasticity (E) of 37.97 $\mathrm{MPa}$, Density $(\rho) 193(\mathrm{~kg} / \mathrm{m} 3)$ and Thermal conductivity $0.096 \mathrm{~W} / \mathrm{m}$.

3) The results of the free fall drop test inform that there are differences between the testing parameters of M4A bicycle helmets and commercial helmets. In commercial bicycle helmets, the tensile stress ( $\sigma \mathrm{i})$ is $3.78 \mathrm{MPa}$ and the energy impact (Ei) is 555.64 joules. Comparing to the value of absorbed energy from a commercial helmet, the value of the helmet parameters tested in this study is much smaller at 283.77 joules, approaching the CPSC standard threshold value of 90 to 110 joules.

4) Bicycle helmet models produced in this experiment are Half Face - BMX Helmet, M4A models, $264 \mathrm{~mm}$ in length of dimension, $184 \mathrm{~mm}$ in width, and $154 \mathrm{~mm}$ in height with a head circumference of $580 \mathrm{~mm}$ (M size), 11 ventilations, 10 $\mathrm{mm}$ thickness and $331 \mathrm{~kg}$ mass.

\section{REFERENCE}

1. Campbell, D.T et. Al. Hybrid Thermoplastic composite ballistic helmet fabrication study, Society for Advancement of material and process engineering, 2008.

2. Archer, Bruce, 'Design as a discipline', Design Studies, Vol 1, No 1, July 2001, pp.17-20.

3. Jones, John Christopher, Design Methods: seeds of human futures, John Wiley \& Sons Ltd., London, 1998; 2nd edition, John Wiley \& Sons Ltd., 1992.

4. Bagas, Evaluasi Ergonomi dalam Desain. Surabaya: Proceeding Seminar Nasional Ergonomi, Jurusan TI - ITS. 2000.

5. Consumer Product Safety Commission, 16 CFR Part 1203 /Federal Register / Vol. 63, No. 46 / Tuesday, March 10, 1998 / Rules and Regulations.

6. Pearce, J.M And Kemp, C., Acoustic Dumping Using Polyurethane / Polymer Composites, (online), (http//www.appropedia.org). diakses tanggal 11Agustus 2017.

7. Subiyanto, Bambang, dkk. Utilization of Empty Fruit Bunch Waste from Oil Palm Industry for Particleboard Using Phenol Formaldehyde Adhesive. Warta PPKS 1-4, 2008.

8. Gunawan, F.E., dkk, Mechanical properties of Oil Palm Empty Fruit Bunch Fiber, Journal of Solid Mechanics \& Materials Engineering, Vol. 3., No. 7, 2009.

9. Fergyanto E.G, Homma H, Satryo S B, dkk: Mechanical Properties of Oil Palm Empty Fruit Bunch Fiber., Journal of solid Mechanics and Material Engineering, hal 943-951, vol.3 No. 7, 2009. 